\title{
Ruokajärjestelmämalli lähiruoan kestävyyden monitieteiseen tutkimukseen
}

\author{
${ }^{1)}$ Soveltavan biologian laitos, PL 27, 00014 Helsingin yliopisto \\ ${ }^{2)}$ MTT Maa- ja elintarviketalouden tutkimuskeskus \\ ${ }^{3)}$ Ruralia instituutti, Helsingin yliopisto
}

Juha Helenius $^{1}$, Esa Aro-Heinilä ${ }^{2}$, Reija Hietala-Koivu ${ }^{1}$, Hanna Ketomäki ${ }^{1}$, Minna Mikkola ${ }^{1}$, Helmi Risku-Norja ${ }^{2}$, Laura Seppänen ${ }^{3}$, Marko Sinkkonen ${ }^{2}$, Antto Vihma ${ }^{2}$ ja Hanna Virtanen ${ }^{2}$

\section{Tiivistelmä}

Paikallinen ruokajärjestelmä, lähiruoka, on erityisesti globaalistuvan ruokajärjestelmän vastakohtana kiinnostava tutkimuskohde. Ruokajärjestelmän paikallistamisella tavoitellaan ruoan tasaveroista ja yhteisöllisesti omatoimista saavutettavuutta, taloudellista ruokaturvaa sekä vastuullisuutta ruoan tuotannon luonnonvaroista ja tuotantoympäristöstä. Nämä tavoitteet liittyvät läheisesti väestö-, talous-, ympäristö- ja kulttuurisiin kysymyksiin analyysin mittakaavasta riippumatta.

Olemme tutkineet ruokajärjestelmän paikallistamisen vaikutuksia ja siihen liittyviä oppimishaasteita kunta- ja maakuntatasolla Etelä-Savossa. Tämänkaltainen kansallista mittakaavaa paikallisempi lähiruoka-ajattelu ilmaantui etenkin maaseudun toimijoiden hankkeisiin 1990-luvun loppupuolella reaktiona maaseudun elinolojen ja -keinojen taantumiseen. Hankkeessa kehitimme monitieteiseen kommunikointiin ja tieteiden-väliseen yhdistämiseen tähtäävän käsitteellisen LOFO järjestelmämallin. Mallissa ruokajärjestelmän ajatellaan muodostuvan kolmesta osajärjestelmästä, jotka olivat yhteiskunnallis-taloudellinen, biofysikaalinen sekä toiminnan osajärjestelmä.

Yhteiskunnallis-taloudellinen osajärjestelmä sisältää normatiivisen ja taloudellisen 'ympäristön', samaan tapaan kuin biofysikaalinen osajärjestelmä sisältää fyysisen ja biologisen ympäristön. Näiden ehdoilla, niihin sopeutuen ja niitä muuntaen kaikki toiminnan osajärjestelmän osakkaat tuottajasta ruoan kuluttajaan toimivat ja tekevät ruokajärjestelmää koskevia päätöksiä. Teimme jokaista osajärjestelmää koskien menetelmällisiä rajauksia ja valintoja, ja toteutimme osajärjestelmäkohtaiset osatutkimukset menetelmällisesti erillisinä tieteenalakohtaisina harjoitelmina. Näin ollen tuloksemme ovat ikäänkuin näytteitä tai palasia systeemimallin tarjoamaan kokonaisvaltaisempaan palapeliin.

Toiminnan osajärjestelmään sisältyy keskeisen tärkeänä ruokajärjestelmään osallisten 'voimaannuttaminen' sekä lisäksi prosessi, jossa paikalliset yhteisöt neovottelevat yhteisestä tulevaisuudestaan ja tunnistavat sen mahdollisuuksia. Lisäksi tuloksemme tukevat ruoan 'valuma-alue' (foodshed) -ajattelua: on välttämätöntä sisällyttää sekä maatilojen ja maaseudun ruoan 'lähde'- (source) että taajamien ja kaupunkien ruoan 'kohde'- (sink) alueet paikallisen järjestelmän rajauksen sisään.

Asiasanat: alue-ekologia, aluetalous, biologinen diversiteetti, lähiruoka, malli, oppiminen, paikallisuus, ruokajärjestelmä, taloudellinen diversiteetti, toimija, ympäristövaikutus. 


\section{Johdanto}

Samanaikaisesti kun globaalin väestön odotetaan kasvavan 9 miljardiin vuoteen 2050 mennessä, ruoantuotantoon käytettävissä oleva maatalousmaa-ala henkeä kohden vähenee. Kriittiset resurssit kuten vesi ja kasvinravinteet ovat yhä rajallisempia, ja tuotannon ympäristövaikutukset kasautuvat hälyttävästi (Tilman et al. 2001). Siksi on tärkeää kysyä, miten maatalousekosysteemit tulisi allokoida väestöjen kesken. Allokoinnin perustavin kriteeri on ruokaturvan kestävä varmistaminen.

Elintarvikekaupan ja maatalouspolitiikan kehityskulut ovat merkittävästi vaikuttaneet maatalouden ja elintarviketeollisuuden resurssien käyttöön sekä kohdentumiseen. Kehitys ohjaa niitä kohti erikoistumista ja horisontaalista integraatiota (esim. Feenstra 1998, Arndt ja Kierzkowski 2001). Samalla on kuitenkin havaittavissa vertikaalista integraatiota joka ilmenee teollisten tuotantoketjujen sisäisenä yhdenmukais-tumisena, kontrollina ja toimintojen tehostumisena (esim. Eckel 2003).1 Tällainen kehitys on ollut erityisen nopeaa nimenomaan elintarvike- ja tekstiilisektoreilla, jolloin voimme puhua myös elintarviketuotannon teollistumisesta eli agroindustrialisaatiosta.

Lähiruoka kiinnostaa sekä ekologian että yhteiskunta- ja taloustieteiden tutkimuskohteena: siitä on muodostunut eräs vaihtoehtoisen kehityksen hypoteeseistä maatalous- ja elintarvikesektorille (Kloppenburg et al. 1996, Bellows \& Hamm 2001). Talouden toiminnan tehostuminen talouden mittakaavaetujen ja suhteellisen edun hyödyntämisen seurauksena ei automaattisesti takaa vapautuvien resurssien kohdentumista muille toimialoille, vaan vajaakäytön riski on todellinen (Martin \& Sunley 1996, 275). Sekä globalisaatio että vaihtoehtoiset ruokajärjestelmät ovat toimijoiden aikaansaannoksia. Tällöin on perusteltua tutkia ruokajärjestelmiä myös konkreettisten toimintojen ja toimijoiden kautta. Ruokajärjestelmien usein krittiisetkin epäkohdat korostavat muutoksen ja oppimisen tärkeyttä, ja ne taas voivat toteutua vain paikallisissa toiminnoissa.

\section{LOFO -ruokajärjestelmämalli}

Ruokajärjestelmän käsitteellinen malli koostuu kolmesta vuorovaikuttavasta osajärjestelmästä (Kuva. 1). Aineellista osa kutsutaan biofysikaaliseksi osajärjestelmäksi. Tuttuja osajärjestelmän analyysitapoja ovat mm. elinkaari- ja materiaalivirta-analyysit. Ihminen biologisena kuluttajapopulaationa myös sisältyy biofysikaaliseen osaan. Toiminnan osajärjestelmässä ihmiset tulkitaan toimijoiksi ja päätöksentekijöiksi. Päätökset voivat edustaa yhteisöllistä oppimista, jota lähiruokaketjun toimijoiden läheisyyden voi olettaa edistävän. Oppiminen ja päätöksenteko ovat olennaisia tulkittaessa sitä, miten biofysikaalista osaa käytetään, seurataan, ohjataan ja muovataan niin strategian kuin taktisella tasolla (Forrester 1992).

LOFO-mallin (Kuva 1) sosioekonominen osajärjestelmä on sekä järjestelmän kuvaus että työkalu sosiaalisten ja taloudellisten rakenteiden vuorovaikutussuhteiden havainnollistamiseen. Sosioekonominen osajärjestelmä sekä mahdollistaa että rajoittaa päätöksentekon ruokajärjestelmässä (“säätely” kuvassa 1). Ruokajärjestelmän toimijat voivat toimia politiikan tai taloudellisen päätöksenteon kautta muuttaakseen sosioekonomista järjestelmää. Sosiologisesti tai markkinointiin painottuneessa ruokajärjestelmätutkimuksessa käytetään esim. tuotejärjestelmä- ja toimijaverkkokäsitteitä ja -teorioita (commodity systems, systems of provision, actor network, food supply chain) (esim. Friedland 1984, Fine et al. 1996, Marsden et al. 2000). Näihin verrattuna LOFO-malli erottelee sosioekonomisen osan toiminnan ja oppimisen osajärjestelmästä, sekä tuo biofysikaalisen osan mukaan.

\section{Tapaustutkimus}

Tutkimuksen kohdealueena oli Juva kunta ja ympäröivä Etelä-Savon maakunta. Juvan 7500 asukkaasta noin puolet toimii maa-, elintarvike- ja metsätaloudessa. Erityisesti Juvan kunta on kehitysstrategiassaan vahvasti sitoutunut kotimaiseen ruoantuotantoon (Kakriainen, 2004). Näinollen on kiinnostavaa selvittää, missä määrin kunnan oma ruokahuolto (koulut, päiväkodit, terveyskeskus jne.) voisi perustua lähiruokaan.

\footnotetext{
1 Horisontaalinen integraatio ulkoistaa toimintoja ja synnyttää ketjumaisia yritysliittymiä, esim. kauppaketjuja. Vertikaalisessa integraatiossa esimerkiksi tuotteen jalostaja tai myyjä hallitsee myös alkutuotantoa ja välitysverkostoa.
} 


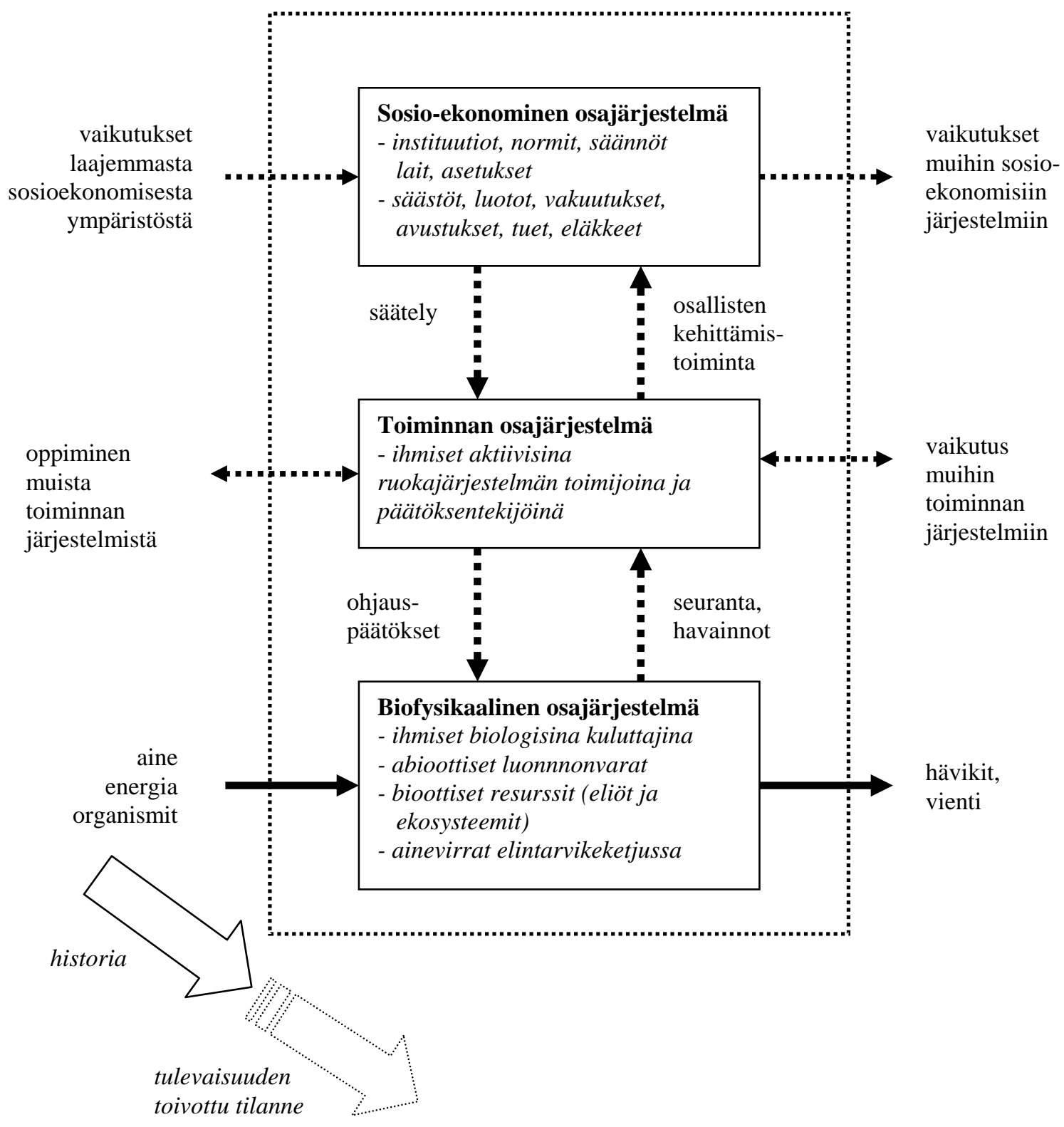

Kuva 1. 'LOFO' (LOcal FOod) -ruokajärjestelmämalli. Yhtenäiset nuolet kuvaavat ainetta ja energiaa, katkonuolet kuvaavat informaatiota (Helenius et al. 2005).

\section{Lähiruokaan siirtymisen ympäristövaikutusten arviointi}

Lähiruokajärjestelmän toteutettavuutta tarkasteltiin neljän erilaisen ruokavalion pohjalta: nykyinen keskimääräinen suomalainen ruoankulutus, ravitsemussuositusten mukainen ruokavalio, maito-riista-kalakasvisruokavalio ja vegaaniruokavalio. Ruokavaliot on koostettu siten, että ne ovat ravitsemuksellisesti tasapainoisia ja niiden energiasisältö on sama. Jokaisessa vaihtoehdossa tarkasteltiin erikseen tavanomaiseen ja luomutuotantoon perustuvaa lähiruokaa. Tarkastelu ulotettiin kolmelle eri aluetasolle (kunta, kuntayhtymä, maaseutukeskus), ja muutoksia verrattiin tilanteeseen vertailuajankohtana vuonna 2002. Ympäristö-vaikutusten arviointi perustui maatalouden maankäyttöön sekä panoskäyttöön. Käytettävissä oleva peltoala mahdollistaa lähiruokajärjestelmän toteutumisen ruokavaliovaihtoehdosta riippumatta kaikilla kolmella aluetasolla, joskin toteutuminen vaatisi jonkin verran maatalouden tuotantosuuntien uudelleenjakautumista.

Ympäristökuormitusta arvioitiin ravinnetaseiden (Oenema 2003), kasvihuonekaasu- ja happamoittavien päästöjen sekä maisemavaikutusten osalta. Tutkimuksessa oletettiin, etteivät pellon ulkopuoliset 
alueet muuttuisi maankäytöltään lähiruokajärjestelmään siirryttäessä ja siksi tarkastelu rajattiin viljelykasvimonimuotoisuuteen ja sen muutoksiin, mitä kuvattiin Shannonin diversiteetti-indeksillä (SHDI; McGarigal \& Marks 1995). Tarkastelu rajattiin maatalouteen, joten kuljetusten vähentymisen ympäristöhyötyjä ei ole otettu huomioon.

Ympäristökuormituksen suhteen eri ruokavaliovaihtoehdot eivät juurikaan eroa toisistaan. Shannon-indeksin perusteella luonnonmukaisesti tuotettu kasvisruokavalio on viljelykasvien monimuotoisuuden kannalta edullisin, se vähentäsi myös eniten kaasumaisia päästöjä ilmakehään ja olisi ravinne-kuormituksenkin kannalta vähiten kuormittava. Pellonkäytön suhteen monimuotoisin maisema vähentää kuitenkin monivuotisten laidunten ja nurmien viljelyalaa, ja saattaa sen vuoksi vähentää maatalousympäristön luonnoneliöiden monimuotoisuutta. Luonnon monimuotoisuuteen vegaaniruokavaliolla näyttäisikin siten olevan epäedullinen vaikutus.

\section{Lähiruoan sosioekonomisten vaikutusten arviointi}

Tutkimuksen taloudellisen osan tarkoituksena on tarkastella kerroinvaikutuksia, jotka aiheutuvat lisääntyvästä elintarvikeomavaraisuudesta lähiruoan käytön seurauksena. Tarkastelun kohdealueeksi valittiin Etelä-Savon maakunta yksittäisen kunnan sijasta. Taloudellisen aineiston saatavuus ja toisaalta aluetalouksien avoimmuus puoltavat laajaa lähiruoka-alueen rajausta. Paikallisuus voi taloudellisessa tarkastelussa vaihdella vapaasti jatkumolla $0 \%-100 \%$.

Taloudellisesta näkökulmasta ruoan paikallisuus määrittyy sen arvonmuodostuksen kautta. Mitä suurempi osa ruoan arvonlisästä syntyy alueella ja kohdentuu paikallistalouteen, sen suuremmat ovat sen aikaansaamat kerroinvaikutukset. Koska sekä tuotos että käytetyt panokset vaikuttavat yhteiskunnan hyvinvointiin, on tärkeää arvioida vaihtoehtoiskustannuksia eli menetettyjä muita tuotantomahdollisuuksia, joita aiheutuu panosten kohdentamisesta tiettyyn tarkoitukseen. Alueen taloudellinen menestys on vahvasti riippuvainen niin sanotun alueellisen kerroinvaikutuksen suuruudesta. Kerroin kuvaa paikallisten resurssien käytön osuutta alueen talouden resurssien kokonaiskäytöstä (esim. Archer 1976). Mitä monipuolisempi alueen talouden ja tuotannon rakenne on, sitä suuremmat ovat tuotannon kerroin-vaikutukset, jotka aiheutuvat alueen sisäisen tai ulkoisen kysynnän lisääntymisestä (Mulligan 1994, Säynätmäki 2000).

Lähiruoan taloudellisten vaikutusten analysointia varten hankkeessa luotiin RegAE-laskentamalli, sovellettu panos-tuotosmalli, jonka avulla arvioidaan julkisen ja yksityisen elintarvikekysynnän muutoksien vaikutuksia kohdealueella (mallista tarkemmin kts. Helenius et al. 2005). Talouden rakenne kuvataan alueen toimialojen välisten panos-tuotossuhteiden avulla, jolloin yhdelle toimialalle kohdistuva lopputuotteiden kysynnän muutos välittyy talouden muille toimialoille muuttuneena välituotekysyntänä. Alueen ulkopuolinen tuotanto on kuvattu tuontina alueen toimialoille ja lopputuotekysyntään. Panostuotos -mallintaminen sopii parhaiten lyhyen aikavälin tarkasteluun ja kuvaa tarkasti vain suhteellisen pieniä muutoksia toimialojen välisissä suhteissa

Lähiruoan taloudellisia vaikutuksia voidaan tarkastella kahdella tasolla: Lopputuotekysynnän muutoksia arvioidaan keskivertokuluttajan ostoskorin sisällön perusteella, jolloin kokonaisostovoima pysyy samana mutta korin sisältö muuttuu. Kysynnän kohdentuminen eri tuotteisiin kuin ennen vaikuttaa elintarvikkeiden tuottajiin eri tavoin, ja muuttaa talouden sektoreiden keskinäisiä suhteita. Toinen askel on tarkastella lisääntynyttä alueellista välituotteiden panoskäyttöä elintarvikesektorilla.

\section{Toiminta ja oppiminen ruoan paikallistamisessa}

Oppiminen ja toimijoiden osallistuminen ruokajärjestelmän toimintaan on oleellinen osa kestävää kehitystä (O’Riordan \& Voisey, 1997). Toiminnan osajärjestelmässä ihmiset monitoroivat ja johtavat biofysikaalista ja yhteiskunnallis-taloudellista osajärjestelmää.

Ruokajärjestelmien toiminnan ja oppimisen analyysissa käytetään kahta ulottuvuutta, joista toinen on elintarvikeketjujen keskittyneisyys tai hajaantuneisuus. Toinen ulottuvuus on ketjujen toimijoiden välisten suhteiden laatu: Beusin ja Dunlapin (1990) mukaan tavanomaisille ruokaketjuille on tyypillistä hierarkkiset ja markkinalliset suhteet, kun taas vaihtoehtoisten ruokajärjestelmien suhteet perustuvat enemmän luottamukseen, kumppanuuten ja yhteisöön. 
Konsepti A

Pienet jaot isoista yksiköistä

Konsepti B

Yhteistyöllä eteenpäin
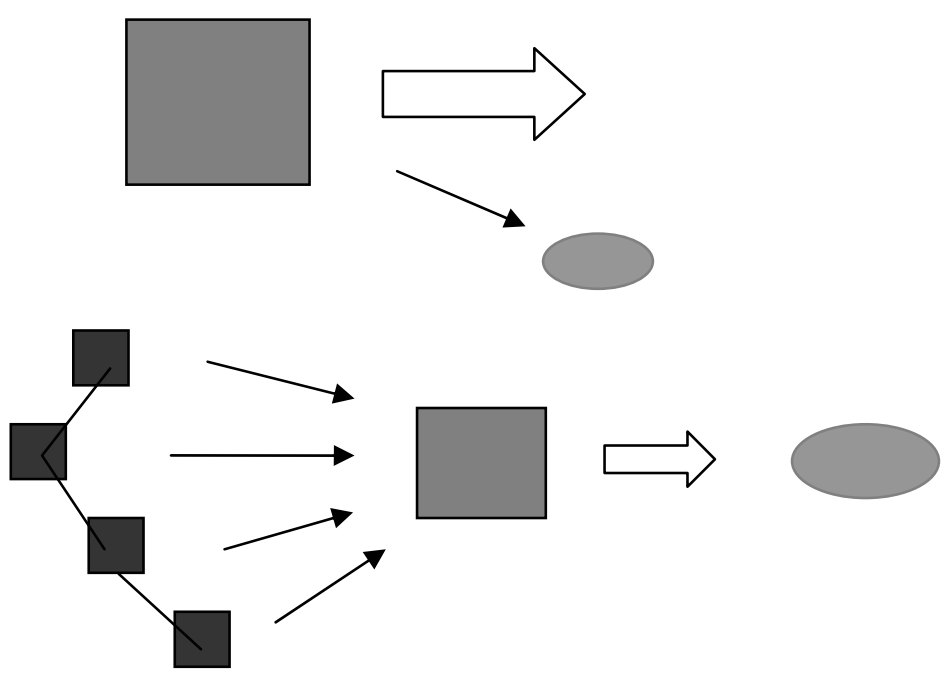

Konsepti C

Pienuus kilpailuetuna?

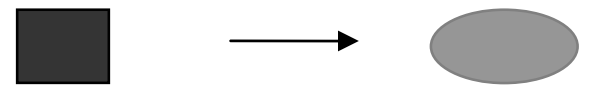

Kuva 2. Kolme lähiruokaketjujen konseptia. (Seppänen 2005a)

\section{Oppimishaasteiden sekä toimijoiden suhteiden analyysit}

Merkittävän oppimisen perusta ovat ihmisten omissa, paikallisissa toiminnoissa muodostuneet oppimishaasteet (Seppänen 2005b). Aineistona oppimishaasteiden tutkimiselle oli ruokajärjestelmän toimijoiden yhteinen keskustelu, jossa luomu- ja lähiruoan kehittäminen nähtiin kahden erilaisen toimintalogiikan näkökulmista.

'Pienen' toimintalogiikka puolustaa pienviljelijöitä ja korostaa lähiruoan hyötyjä ympäristölle, hyvinvoinnille ja aluetaloudelle. 'Suuren' toimintalogiikan myötä katsottuna vaihtoehtoisten ketjujen arvo on niiden kilpailuedussa markkinoilla. Vuoropuhelu tuotti erilaisia konsepteja lähiruoan organisoimiseksi tuottajalta ostajalle (Kuva 2). B-konsepti korostaa tuottajien keskinäistä yhteistyötä elintarvikkeiden jatkojalostuksessa tai jakelussa. Se on toimivan ja kestävän lähiruoan ketjun hypoteesi, koska se voi sekä yhdistää hajauttavia ja keskittäviä suuntauksia että lisätä paikallisten tuottajien osallistumismahdollisuuksia ketjun toimintaan.

Elintarvikeketjujen vaihtosuhteita kategorisoitiin markkina-, hierarkia- ja kumppanuussuhteiksi (Powell 1990, Powell \& Smith-Doerr 1994). Kategoriat eivät ole selvärajaisia,vaan esim. hierarkkinen suhtautuminen voi painottua markkinasuhteen tai kumppanuusuhteen suuntaan. Yksittäisillä toimijoilla voi olla monia suhteita 'hoidettavanaan'; toimijoiden sosiaalinen taidokkuus on ilmeisesti tärkeä tekijä ketjujen kehityksessä. Hierarkkiset ainekset olivat selvästi näkyvissä suurissa ketjuissa joissa suuret elintarvikemassat liikkuivat. Joissakin suurissa osuustoiminnallisissa ketjuissa ilmeni myös kumppanuuden piirteitä. Pienet ketjut olivat suuria riippuvaisempia paikallisista sosiaalisista suhteista ja niiden tarjoamasta tiedosta, jonka avulla voitiin päästä paikallisille markkinoille rakentamalla kumppanuus- tai markkina-suhteita.

Huomattava osa paikallisista toimijoista maatalousvaltaisilla alueilla toimii suurten ketjujen osana, ja heidän toimintansa voidaan nähdä kansallisen tason paikallistamisena. Osa paikallisista toimijoista kuuluu alueellisiin ketjuihin; yhteistyö perustuu usein paikallisen kehityshistorian pohjalle rakentuneisiin sosiaalisiin suhteisiin, jotka edelleen kehittyvät taloudellisiksi kumppanuussuhteiksi. 


\section{Lähestymistavan tarkastelu}

Hankkeessamme empiirinen aineiston ja analyysin mittakaava vaihteli talousalueesta kunnan ja yksittäisten elintarvikeketjujen tasoon. Tilanne haastoi arvoimaan tieteenaloittaisen osajärjestelmäanalyysin soveltuvuutta lähiruoan kestävyyden kaltaiseen kompleksiseen kysymykseen. Onko mahdollista tarkastella järjestelmä-kokonaisuutta näiden menetelmävalintojen ja niihin sidottujen tulosten pohjalta? Jatkossa tulisikin hakea täydentäviä otteita, joissa huomio kiinnitettäisiin osajärjestelmien välisiin vuorovaikutuksiin osajärjestelmien sisäisten prosessien ja lainalaisuuksien sijasta.

Hankkessa ei arvioitu järjestelmän ulkopuolelle, esim. talousalueen rajojen taakse, kohdistuvia ympäristö- tai talousvaikutuksia. Tämä on seurausta tukeutumiesesta malleihin, jotka vaativat systeemin rajojen subjektiivisen määrittelyn. Kuitenkin, mikä lisää kestävyyttä paikallisesti, tulisi lisätä tai olla vähintään neutraali kestävyydelle globaalisti. Ympäristövaikutusten analyysi kohdistui maaseutualueeseen, joka on maataloustuotteiden nettoviejä. Pääosa maatalousmaasta oli allokoitu alueen ulkopuolisten taajamien ja kaupunkien ruoankulutukseen, joten suurin osa ainevirroista jäi systeemirajan taakse.

Urbaanit ja niiden läheiset alueet ovat maaseutualueita monipuolisempia taloudelliselta rakenteeltaan. Tämän vuoksi erikoistuminen johtaa maaseudulla usein taloudellisen monimuotoisuuden vähenemiseen, koska se kohdentuu vähän talouden lisäarvoa tuottavaan perustuotantoon, jolloin palveluiden ja työvoiman kokonaiskysyntä vähenee. Myös erikoistuvan alkutuotannon panokset tuodaan usein alueen ulkopuolelta, jolloin investointeihin käytetyt rahat vuotavat pois aluetaloudesta.

Toiminnan osajärjestelmään sisältyy keskeisen tärkeänä ruokajärjestelmään osallisten 'voimaannuttaminen' sekä lisäksi prosessi, jossa paikalliset yhteisöt neovottelevat yhteisestä tulevaisuudestaan ja tunnistavat sen mahdollisuuksia (O'Riordan \& Voisey 1997). Lisäksi tuloksemme tukevat ruoan 'valumaalue' (foodshed) -ajattelua (kts. Kloppenburg et al. 1996): on välttämätöntä sisällyttää sekä maatilojen ja maaseudun ruoan 'lähde'- (source) että taajamien ja kaupunkien ruoan 'kohde'- (sink) alueet paikallisen järjestelmän tai 'lähiruoan' rajauksen sisään.

Kiitokset: Kiitämme useita hankkeen suunnittelun eri vaiheissa osallistuneita kollegoja, erityisesti Helena Kahiluotoa ja Anja Yli-Viikaria. Hankkeen rahoittaja on MMM.

\section{Viitteet}

Archer, B. H. 1976. The anatomy of a multiplier. Regional Studies 10: 71-77.

Arndt, S.W. \& H. Kierzkowski (ed.). 2001. Fragmentation. New Production Patterns in the World Economy. Oxford: Oxford University Press. 268 p.

Bellows, A.C. \& M.W. Hamm 2001. Local autonomy and sustainable development: testing import substitution in localizing food systems. Agriculture and Human Values 18: 271-284.

Beus, C. E. \& Dunlap, R. E. 1990. Conventional versus alternative agriculture: the paradigmatic roots of the debate. Rural Sociology 55(4): 590-616.

Eckel, C. 2003. Does globalization lead to specialization. CeGE Discussion paper 20. 27 p. Available on the internet: http://www.cege.wiso.uni-goettingen.de/Dokumente /Diskussion/20_Eckel.pdf.

Feenstra, R.C. 1998. Integration of Trade and Disintegration of Production in the Global Economy. Journal of Economic Perspectives 12, 4: 31-50.

Fine, B., M. Heasman \& J. Wright 1996. Consumption n the Age of Affluence: The World of Food. Routledge, London.

Forrester,J.W. 1992. Policies, decisions and information sources for modeling. European Journal of Operational Research 59: 42-63.

Friedland, W.H. 1984. Commodity systems analysis: an approach to the sociology of agriculture. In: H.K. Schwarzweller (ed.) Research in Rural Sociology and Development: A Research Annual. JAI Press, Greenwich, Connecticut. Pp. 221-235.

Helenius, J., E. Aro-Heinilä, R. Hietala-Koivu, M. Mikkola, H. Risku-Norja, L. Seppänen, M. Sinkkonen \& A. Vihma 2005. Systems frame for multidisciplinary study on sustainability of localizing food. 11th Ann. Int. Sust. Dev. Res. Conf., June 6-8, 2005, Helsinki. 16 p. (Proc. CD-Rom) 
Kakriainen, S. 2004. Juva, Finland - Developing local food with common goals and projects. In: Laura Seppänen (Ed.). Local and Organic Food and Farming around the Baltic Sea. Ecological Agriculture, 40. Centre for Sustainable Agriculture, Swedish University of Agricultural Sciences. http://www.cul.slu.se /english/information

Kloppenburg, J. Jr., J. Hendrickson \& G.W. Stevenson 1996. Coming in to the foodshed. Agriculture and Human Values 13: 33-42.

Marsden, T., J. Banks \& G. Bristow 2000. Food supply chain approaches: exploring their role in rural development. Sociologia Ruralis 40: 424-438.

Martin, R. \& P. Sunley 1996. Paul Krugman's Geographical Economics and Its Implications for Regional Development Theory: A Critical Assessment. Economic Geography 72, 3: 259-292.

McGarigal, K. \& B.J. Marks 1995. FRAGSTATS: spatial pattern analysis program for quantifying landscape structure. U.S. Forest Service General Technical Report PNV 351.

Mulligan, G.F. 1994. Multiplier effects and structural change: Applying economic base analysis to small communities. Review of Urban and Regional Development Studies 6: 3-21.

Oenema, O., H. Kros \& W. De Vries 2003. Approaches and uncertainties in nutrient budgets: implications for nutrient management and environmental policies. European Journal of Agronomy 20: 3-16.

O’Riordan, T. \& H. Voisey 1997. The political economy of sustainable development. Environmental Politics 1: 123.

Powell WW. 1990. Neither market nor hierarchy: Network forms of organisation. In Staw, B.M. And Cummings, L.L. (Eds.) Research in Organizational Behaviour. An annual series of analytical essays and critical reviews. Vol 12. pp. 295-336. Jai Press inc. London.

Powell, W.W. And Smith.Doerr, L. 1994. Networks and Economic Life. In Smelser, N.J. And Swedberg, R. (Eds.). 1994. The Handbook of Economic Sociology. pp. 368 - 402. Princeton University Press. New Jersey.

Seppänen, L. 2005a. Ketjujen konseptit paikallisten ruokajärjestelmien kehittämisessä. Maaseudun Uusi Aika, arvioitavana oleva käsikirjoitus.

Seppänen, L. 2005b. Societal integration in organic vegetable farming: exploring the learning challenges. In: Yrjö Engeström, Joachim Lompscher and Georg Rückriem (Eds.). Putting activity theory to work. Contributions from developmental work research. Lehmanns Media, Berlin.

Säynätmäki, T. 2000. Maaseudun erilaistuminen ja työllisyys. Helsingin Yliopiston taloustieteen laitoksen selvityksiä nro 11. Helsinki. $88 \mathrm{~s}$.

Tilman, D., J. Fargione, B. Wolff, C. D’Antonio, A. Dobson, R. Howarth, D. Schindler, W.H. Schlesinger, D. Simberloff \& D. Swackhamer 2001. Forecasting agriculturally driven global environmental change. Science 292: 281-284.

Wagner, J.E. \& Deller, S.C. 1998. Measuring the effects of economic diversity on growth and stability. Land Economics 74 (4): 541-556. 